\title{
A NEW APPROACH TO OIL PALM WOOD UTILIZATION FOR WOODWORKING PRODUCTION Part 2: Wood Modification with Organic Resin
}

\author{
Jamal Balfas ${ }^{1}$
}

\begin{abstract}
The first stage of this study has demonstrated that oil palm wood has inferior characteristics in comparison with the conventional wood, and suggested to upgrade oil palm wood quality to increase its possible use for woodworking purposes. The use of organic resin (JRP-2) has been examined in this study for improving dimensional stability, strength and machining quality of the oil palm wood. Resin treatment was conducted by frying wood samples in a hot resin solution maintained at 60-80 ${ }^{\circ} \mathrm{C}$. The treated samples were then oven dried to reach $10 \%$ moisture content. After conditioning, wood samples were subjected to various tests. Results indicated that organic resin treatment significantly improved oil palm wood dimensional stability of more than $50 \%$. Machining and strength characteristics of the oil palm wood were markedly improved after the resin treatment. Improved characteristics of the treated oil palm wood were comparable with the quality of conventional timber.
\end{abstract}

Keywords: Wood quality, dimensional stability, characteristic

\section{INTRODUCTION}

Oil palm stem is lignocellulosic in nature, making it a possible alternative in coping with wood scarcity due to the depleting national supply of timber. Development of an appropriate technology for converting the stem into value added end-products will generate additional income to smallholders, and an increase in revenue for the oil palm plantation industry. Additionally, replantations will no longer create environmental/smoke hazard --felled oil palm stems were simply burned until the practice was banned-- or pest hazard for the left felled stems are ideal media for numerous of pests. These positive reasons have geared many efforts in the last three decades to utilize the wasted lignocellulosic material.

Various researchers in several countries have given numerous attentions to determine ways of utilizing the oil palm stem. Results in general suggested that the oil palm stem is a novel material in the field of timber utilization and is not an easy material to process and work with. It has certain unique

1 Forest Products Research and Development Center, Jl. Gunung Batu No. 5, Bogor 16610, Indonesia.E-mail: jamalbs2000@yahoo.com 
characteristics and proffers a vast array of problems that are rarely encountered in any conventional timber. Relationship of costs versus recovery rate and comparable quality of the woodworking products is disadvantageous for the processing of oil palm stems (Shaari et al., 1991). These studies, however, have adopted the existing techniques commonly used to process conventional timbers. In the last six years, The Forest Products Research and Development Center (FPRDC) has created a new approach in timber processing through several application of organic and inorganic modifications which significantly effective in improving the inferior characteristics of low-density timbers and oil palm wood. The method gives a promising prospect of using oil palm stem as substitute material for productions of furniture and building components. This article reports the second part of the study, which describes the effect of organic resin treatment on the characteristics of oil palm wood.

\section{MATERIALS AND METHODS}

\section{A. Test Material}

Oil palm trees representing three varieties (Dura, Picivera and Tenera) were selected from three localities in the province of North Sumatra. The trees were selected according to several criteria as described in the earlier article (Balfas, 2006). All plantations harvested in this context were established in 1973. All trees selected were numbered, felled and cut immediately below the crown. The clear boles were bucked into sections of $2.5 \mathrm{~m}$ length logs. Sample disks were taken at butt and breast height levels, and thereafter at $2.5 \mathrm{~m}$ intervals. Specimens for determination of moisture content and density distribution were cut from each disk within approximately 30 minutes after felling and bucking. Moisture specimens were divided into small blocks and processed immediately. Density specimens were carefully conditioned to equilibrium moisture content.

\section{B. Sample and Resin Preparations}

Oil palm logs were broken down using a band-headrig (BS-60"), and further processed in a band-resaw (BS-44") in accordance with sawing patern shown in Figure 1. Sawblades with tooth pitch of $40-45 \mathrm{~mm}$ were stellite tipped and operated at feed speed ranging from 8 to $15 \mathrm{~m} /$ minute. The outer (high density) and inner (lower density) part of each log was concentrated for producing 30 and $50 \mathrm{~mm}$ boards respectively. All boards were kiln dried to reach air-dry condition, approximately $15 \%$ moisture content. Four sides of the air-dry boards were sound with a double planer. Resin solutions were prepared by diluting pine resin in heated kerosene with two levels of concentration, i.e. 20 and $30 \%$ weight per volume (w/v). 
A New Approach ..... J. Balfas.

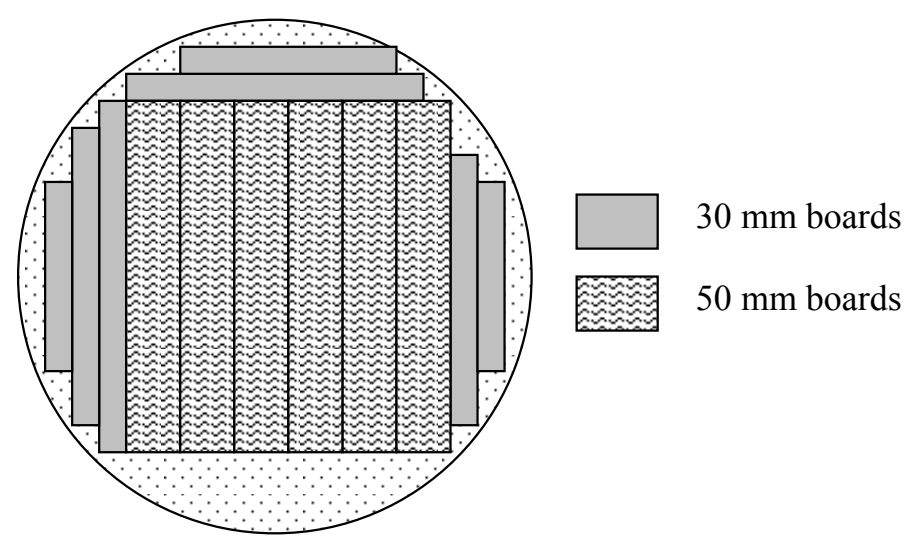

Figure 1. Sawing pattern used for producing 30 and $50 \mathrm{~mm}$ planks

\section{Treatment Application}

The sound boards measuring $20 \mathrm{~mm}$ thick, $200 \mathrm{~mm}$ wide and $2000 \mathrm{~mm}$ long were carefully measured and weighted prior to treatment. The boards were fried in a long tank filled with hot resin and maintained at $60-80{ }^{\circ} \mathrm{C}$. Each frying work was conducted for 10 minutes, and the boards were drained after frying. The treated samples were oven dried to reach 10\% moisture content. Boards conditioning was undertaken approximately for 7 days to reach back the airdry moisture content. The treated boards were re-weighted and re-measured to determine weight and dimensional gains due to resin deposition.

\section{Physical and Mechanical Properties}

Samples from each group of observation were prepared from the treated and untreated boards. Physical and mechanical measurements followed the method described by Meylan (1978). Mechanical properties include bending, hardness, and compression strengths were determined using a universal testing machine (Shimadzu, $100 \mathrm{KNe}$ ).

\section{E. Machining Tests}

Oil palm boards of the treated and untreated samples were subjected to machining tests. The tests include planning, shaping, boring and sanding operations. Conventional machineries fashioned to industry standards were used for conducting different testing operation. Testing procedures were carried out according to ASTM D.1666-64 (1974) with some modifications to meet several test requirements. 


\section{F. Experimental Design}

Variables observed in this study consisted of two main factors, i.e. species variety and resin treatment. The first factor consisted of three varieties, i.e. Dura, Picivera and Tenera. The second factor has three levels of resin concentration, i.e. $O$ (control), 20 and $30 \%$ weight per volume $(\mathrm{w} / \mathrm{v})$. A complete factorial design was applied in analyzing data for each parameter observed in this study.

\section{RESULTS AND DISCUSSION}

Average dimensional and weight gains due to resin deposition significantly vary in accordance with species variety and resin concentration (Table 1). However, changes within a variety were mostly not significantly different in relation with resin concentration. Dura experienced fewer changes in thickness and weight than the two other varieties. The greatest physical changes were encountered on picivera samples. These phenomena were particularly related with wood density of each variety (Table 2 ). Wood with a higher density absorbed less resin than that of a lower density. Correlation coefficients $\left(\mathrm{R}^{2}\right)$ of each wood variety for density and resin absorption relationship were quite high ranging from 0.67 to 0.82 . The difference is explicable since the lighter wood possesses more void structure (parenchymatous tissues), which means more resin sorption sites available than those in the heavier ones (Lim and Khoo, 1986).

Table 1. Average weight and dimensional changes due to resin treatment

\begin{tabular}{lccccccc}
\hline \multirow{2}{*}{ Variety } & $\begin{array}{c}\text { Resin con- } \\
\text { centration } \\
(\%)\end{array}$ & \multicolumn{2}{c}{ Thickness $(\mathrm{mm})$} & \multicolumn{2}{c}{ Weight $(\mathrm{gr})$} & \multicolumn{2}{c}{ Changes (\%) } \\
\cline { 3 - 8 } Dura & 20 & 20.8 & 22.1 & 8,651 & 9,682 & $6.25 \mathrm{a}$ & $11.92 \mathrm{a}$ \\
& 30 & 21.1 & 22.4 & 8,708 & 10,044 & $6.16 \mathrm{a}$ & $15.34 \mathrm{ab}$ \\
\multirow{2}{*}{ Picivera } & 20 & 21.2 & 24.8 & 5,308 & 6,830 & $16.98 \mathrm{c}$ & $28.67 \mathrm{c}$ \\
& 30 & 20.9 & 24.6 & 5,322 & 6,980 & $17.70 \mathrm{c}$ & $31.15 \mathrm{c}$ \\
& 20 & 21.1 & 24.2 & 6.375 & 7,576 & $14.69 \mathrm{~b}$ & $18.84 \mathrm{~b}$ \\
Tenera & 30 & 20.8 & 23.9 & 6,421 & 7,704 & $14.90 \mathrm{~b}$ & $19.98 \mathrm{~b}$ \\
\hline
\end{tabular}

Note: Values within a column followed by the same letter are not significantly different by Tukey test, $\mathrm{p}<0.05$ 
Higher resin concentration in general gave more additional gains on dimension and weight of the wood than those treated with lower resin concentration (Table 1). However, the changes on the two parameters were approximately similar for the different resin concentration. These values indicate that the use of $20 \%$ resin concentration is sufficient in improving wood dimensional stability.

Resin treatment on oil palm wood has resulted in numerous changes on moisture content and density of the wood (Table 2 ). The treatment significantly $(p<0.01)$ decreased the initial moisture content and increased density of each wood variety. Moisture content decrement may be due to the replacement some of wood-moisture links with wood-resin links. This means less moisture sites available in the treated wood, hence improving wood dimensional stability. Table 3 shows significant reductions on water absorption of the treated specimens during soaking. Water absorption reductions could reach more than 50\% depending on wood variety. Such effect is very important in increasing possible use of oil palm wood which solving one weakness of the wood characteristics (Balfas, 2006).

Table 2. Changes on moisture content and density due to resin treatment

\begin{tabular}{|c|c|c|c|c|c|c|c|}
\hline \multirow[b]{2}{*}{ Variety } & \multirow{2}{*}{$\begin{array}{c}\text { Treatment } \\
(\%)\end{array}$} & \multicolumn{2}{|c|}{ Moisture content (\%) } & \multicolumn{2}{|c|}{ Density $\left(\mathrm{gr} / \mathrm{cm}^{3}\right)$} & \multicolumn{2}{|c|}{ Changes (\%) } \\
\hline & & Before & After & Before & After & $\begin{array}{l}\text { Moisture } \\
\text { content }\end{array}$ & Density \\
\hline \multirow[t]{3}{*}{ Dura } & 0 & 15.24 & - & 0.48 & - & - & - \\
\hline & 20 & 15.32 & 14.24 & 0.49 & 0.59 & $-7.05 \mathrm{a}$ & $20.41 \mathrm{a}$ \\
\hline & 30 & 15.29 & 14.17 & 0.48 & 0.61 & $-7.33 \mathrm{a}$ & $27.08 \mathrm{~b}$ \\
\hline \multirow[t]{3}{*}{ Picivera } & 0 & 17.68 & - & 0.31 & - & - & - \\
\hline & 20 & 17.70 & 14.65 & 0.30 & 0.46 & $-17.23 c$ & $53.33 \mathrm{e}$ \\
\hline & 30 & 17.71 & 14.63 & 0.31 & 0.49 & $-17.39 c$ & $58.06 \mathrm{f}$ \\
\hline \multirow[t]{3}{*}{ Tenera } & 0 & 16.67 & - & 0.37 & - & - & - \\
\hline & 20 & 16.72 & 14.62 & 0.37 & 0.52 & $-12.56 \mathrm{~b}$ & $40.54 \mathrm{c}$ \\
\hline & 30 & 16.69 & 14.57 & 0.38 & 0.58 & $-12.70 \mathrm{~b}$ & $52.63 \mathrm{~d}$ \\
\hline
\end{tabular}

Note: Values within a column followed by the same letter are not significantly different at Tukey test, $\mathrm{p}<0.05$

Wood density increments due to resin treatment (Table 2) exhibited an obvious variation according to wood variety and resin concentration. Wood with higher initial density experienced less increment than wood having lower 
density. Similar phenomena have been reported earlier in coconut wood treated with different resin (Balfas, 2007). Higher resin concentration resulted in more density increment on each wood variety. This is particularly due to the presence of more solid ingredient in the higher resin concentration, leaving heavier bulking effect in the wood structure.

Oil palm wood could absorb a great amount of moisture during soaking (Table 3). The untreated samples could take up water approximately $5 \%$ of their initial weight within 5 minutes soaking. Such water absorption is commonly found on conventional wood (such as yellow balau, mangium and teak) after 4 hours soaking (Malik and Balfas, 2002). This clearly shows that the oil palm wood is very hygroscopic and less dimensionally stable in comparison with conventional timbers. The application of resin treatment on oil palm wood (Table 3) could significantly reduce water absorption during soaking. This preferable character is simply contributed by the resin polymers which possess high water resistance. However, the effectiveness of resin treatment in retarding water absorption is highly dependent upon wood variety. Wood with higher density experienced higher dimensional improvements than those of lower densities. The use of higher resin concentration did not significantly $(\mathrm{p}<0.05)$ improve water absorption retardation. These phenomena particularly related with the initial oil palm wood characteristics, i.e. the higher density absorbed less water during soaking than the lower density.

Table 3. Water absorption of the untreated and treated samples during soaking

\begin{tabular}{|c|c|c|c|c|c|c|c|}
\hline \multirow{2}{*}{$\begin{array}{l}\text { Treatment } \\
(\%)\end{array}$} & \multirow[b]{2}{*}{ Variety } & \multicolumn{6}{|c|}{ Water absorption (\%) on different soaking time } \\
\hline & & $\begin{array}{c}5 \\
\text { Minutes } \\
\end{array}$ & $\begin{array}{c}10 \\
\text { Minutes }\end{array}$ & $\begin{array}{c}30 \\
\text { Minutes }\end{array}$ & $\begin{array}{c}1 \\
\text { Hour }\end{array}$ & $\begin{array}{c}4 \\
\text { Hours } \\
\end{array}$ & $\begin{array}{c}24 \\
\text { Hours }\end{array}$ \\
\hline \multirow{3}{*}{0} & Dura & 4.77 & 6.50 & 8.10 & 9.76 & 14.38 & 24.54 \\
\hline & Picivera & 5.49 & 7.34 & 9.43 & 11.53 & 17.04 & 33.48 \\
\hline & Tenera & 5.04 & 7.07 & 8.83 & 10.99 & 16.37 & 28.23 \\
\hline \multirow{3}{*}{20} & Dura & 2.22 & 2.96 & 3.14 & 4.37 & 5.81 & 12.95 \\
\hline & Picivera & 3.99 & 5.40 & 6.39 & 7.55 & 13.99 & 20.15 \\
\hline & Tenera & 2.35 & 3.03 & 3.52 & 5.00 & 6.86 & 15.80 \\
\hline \multirow{3}{*}{30} & Dura & 2.56 & 2.98 & 3.68 & 4.33 & 5.30 & 12.23 \\
\hline & Picivera & 4.00 & 5.16 & 6.44 & 7.90 & 12.47 & 20.83 \\
\hline & Tenera & 1.94 & 3.18 & 3.77 & 5.36 & 7.01 & 15.69 \\
\hline
\end{tabular}


Mechanical properties of initial oil palm wood reflected the density variations between varieties. Dura consistently revealed better mechanical properties than Tenera and Picivera (Table 4). Comparison of mechanical properties of oil palm wood with three other species listed in the table clearly shows that values of the former are approximately 10 to $60 \%$ lower. Treatment with organic resin could significantly $(\mathrm{p}<0.01)$ improve mechanical characteristics of oil palm wood. The rate of mechanical improvements varied from 12 to $56 \%$ depending on wood variety and mechanical property. Picifera experienced more mechanical improvements after treatment than the other two varieties. The highest improvements were encountered on the MOE and MOR properties. Application of higher resin concentration did not significantly $(p<0.05)$ give better mechanical improvements in comparison with those treated with the lower ones. Mechanical improvements resulted in the resin treated wood samples may particularly be due to the cementing and bulking effects within the wood structure generated by resin polymers after curing. The treated oil palm wood possesses comparable strength characteristics to those of commercial wood, suggesting that the treated wood may be used as a substitute material to the conventional timber.

Table 4. Wood mechanical properties

\begin{tabular}{|c|c|c|c|c|c|c|}
\hline $\begin{array}{l}\text { Species } \\
\text { variety }\end{array}$ & $\begin{array}{c}\text { Treatment } \\
(\%)\end{array}$ & $\begin{array}{l}\text { Density } \\
\left(\mathrm{g} / \mathrm{cm}^{3}\right)\end{array}$ & $\begin{array}{c}\mathrm{MOE} \\
\left(\mathrm{Kg} / \mathrm{cm}^{2}\right)\end{array}$ & $\begin{array}{c}\text { MOR } \\
\left(\mathrm{Kg} / \mathrm{cm}^{2}\right)\end{array}$ & $\begin{array}{c}\text { Comp./to } \\
\text { Grain (Kg/ } \\
\left.\mathrm{cm}^{2}\right)\end{array}$ & $\begin{array}{l}\text { Hardness } \\
(\mathrm{Kg})\end{array}$ \\
\hline \multirow[t]{3}{*}{ Dura } & 0 & 0.48 & 48,704 & 467 & 392 & 352 \\
\hline & 20 & 0.59 & 64,825 & 581 & 451 & 397 \\
\hline & 30 & 0.61 & 65,630 & 582 & 463 & 391 \\
\hline \multirow[t]{3}{*}{ Picifera } & 0 & 0.31 & 35,720 & 328 & 272 & 262 \\
\hline & 20 & 0.46 & 43,600 & 472 & 387 & 307 \\
\hline & 30 & 0.49 & 46,120 & 477 & 386 & 320 \\
\hline \multirow[t]{3}{*}{ Tenera } & 0 & 0.37 & 44,242 & 436 & 354 & 324 \\
\hline & 20 & 0.52 & 62,040 & 521 & 413 & 363 \\
\hline & 30 & 0.58 & 63,705 & 534 & 420 & 368 \\
\hline \multirow{2}{*}{$\begin{array}{l}\text { Coconut } \\
\text { wood } * *\end{array}$} & Butt* & $>0.60$ & 115,200 & 989 & 582 & 558 \\
\hline & Middle & 0.50 & 72,430 & 641 & 388 & 462 \\
\hline $\begin{array}{l}\text { Rubber } \\
\text { wood } * *\end{array}$ & - & 0.56 & 91,050 & 652 & 271 & 442 \\
\hline $\begin{array}{l}\text { Merkus } \\
\text { pine }{ }^{* * *}\end{array}$ & - & 0.54 & 88,422 & 630 & 268 & 429 \\
\hline
\end{tabular}


The untreated samples of oil palm wood are generally difficult to work with conventional tools. Table 5 shows values of defect free portion of oil palm wood after machining operations in comparison with other commercial wood. Although Dura revealed better machining qualities than two other varieties, these wood materials as a whole possessed poor machining characteristics relative to those of some commercial wood species. The lower machining performances of oil palm wood may be associated with the presence of nonstructural (parenchymatous) tissues in a greater amount than the portion commonly encountered in conventional wood.

Table 5. Wood machining characteristics

\begin{tabular}{lccccc}
\hline \multirow{2}{*}{$\begin{array}{c}\text { Species } \\
\text { Variety }\end{array}$} & \multirow{2}{*}{$\begin{array}{c}\text { Treatment } \\
(\%)\end{array}$} & \multicolumn{4}{c}{ Average defect free (\%) } \\
\cline { 3 - 6 } Dura & 0 & Planing & Shaping & Boring & Sanding \\
& 20 & 86.72 & 52.20 & 42.40 & 64.76 \\
& 30 & 83.51 & 82.51 & 72.28 & 84.61 \\
Picifera & 0 & 44.48 & 34.20 & 27.81 & 47.66 \\
& 20 & 76.33 & 78.12 & 55.69 & 69.60 \\
& 30 & 74.90 & 78.47 & 64.28 & 71.12 \\
Tenera & 0 & 53.44 & 48.56 & 38.30 & 59.80 \\
& 20 & 80.38 & 79.61 & 68.72 & 77.94 \\
& 30 & 81.17 & 78.50 & 69.05 & 76.83 \\
Coconut wood*** & Butt* & 75.74 & 62.51 & 54.48 & 78.70 \\
& Middle & 58.33 & 45.63 & 40.69 & 63.47 \\
Rubber wood ${ }^{* * *}$ & - & 82.25 & 73.20 & 66.75 & 85.19 \\
Merkusii pine ${ }^{* *}$ & - & 84.60 & 79.44 & 72.82 & 87.05 \\
\hline
\end{tabular}

Note: * At breast height $(1.5 \mathrm{~m}) ; * *$ Laboratory notes, Forest Products Research and Development Center

Resin treatment has significantly $(\mathrm{p}<0.01)$ improved machining characteristics on each variety of oil palm wood (Table 5). Machining quality improvements resulted from this treatment varied significantly according to wood variety and machining works. The treated Picifera benefited more machining improvements than the treated other two varieties. The highest improvements were achieved on shaping and boring properties. Application of higher resin concentration did not significantly $(\mathrm{p}<0.05)$ give better machining improvements in comparison with those treated with the lower concentration. This phenomenon is closely similar to the effect of resin treatment on mechanical improvements discussed earlier. Table 5 clearly shows that the treated oil 
palm wood possesses comparable machining characteristics in comparison with several commercial timbers.

\section{CONCLUSIONS}

The untreated oil palm wood had inferior basic characteristics in comparison with commercial timbers. The use of organic resin treatment had significantly improved physical, mechanical and machining characteristics of oil palm wood. The treatment could alter the quality of oil palm wood into new material having comparable quality with that of commercial timber.

\section{REFERENCES}

Anonym. 1974. Standard method of conducting machining tests of wood and wood-base materials. Annual Book of ASTM. Philadelphia.

Anonym. 1995. Annual book of ASTM standards. Sect. 4. Vol 04.10-wood. Philadelphia.

Balfas, J. 2006. New approach to oil palm wood utilization for wood working production, Part 1: Basic properties. Journal of Forestry Research 3(1):5566. Forestry Research and Development Agency, Jakarta.

Balfas, J. 2007. Perlakuan resin pada kayu kelapa. Jurnal Penelitian Hasil Hutan. 25(2):108-118. Pusat Penelitian dan Pengembangan Hasil Hutan, Bogor.

Lim, S.C. and K.C. Khoo. 1986. Characteristics of oil palm trunk and its potential utilization. The Malaysian Forester 49(1): 3-22. Kuala Lumpur.

Malik, J. and J. Balfas. 2002. Modifikasi kayu mangium (Acacia mangium Wild.) dan kemungkinannya untuk penggunaan eksterior dibandingkan dengan kayu jati dan bangkirai. Prosiding Seminar Hasil Penelitian Teknologi Hasil Hutan. tanggal 19 Desember di Bogor. pp. 137-141. Pusat Penelitian dan Pengembangan Teknologi Hasil Hutan. Bogor.

Meylan, B.A. 1978. Density variation within Cocos nucifera stems. New Zealand Journal of Forestry Science 8(3):369-383. Rotorua.

Shaari, K., K.K. Choon, and A.R.M. Ali. 1991. Oil palm stem-Review of research. Research pamphlet No. 107. Forest Research Institute, Malaysia. Kuala Lumpur. 
